\title{
Single-system geology after Arkell
}

\section{Janet V. Watson}

Lower Palaeozoic of the Middle East, Eastern and Southern Africa, and Antarctica: With Essays on Lower Palaeozoic Trace Fossils of Africa and Lower Palaeozoic Palaeoclimatology. Edited by C.H. Holland. Pp.331. ISBN 0-471-27945-5. (Wiley: 1981.) £38, \$84.

"IT HAS been my personal experience that anyone seeking to understand a single geological system must flounder in the literature for some twenty years. ... U Users of this book will be saved some twenty years work". This wry statement comes from the preface to W.J. Arkell's Jurassic Rocks of the World (Oliver \& Boyd, 1956), the first general synthesis of a single system on a world-wide basis. During the quartercentury since its publication the need for regional or global syntheses has increased, and the volume under review is therefore sure of a welcome. It is the third of an ambitious series focused principally on the Cambrian, but taking in Ordovician and Silurian rocks where the nature of the evidence makes precise chronostratigraphy difficult. The regions covered in this volume - the Middle East, north-eastern and southern Africa and Antarctica - are as difficult as any and the decision to cover all of the Lower Palaeozoic systems seems wise.

In introducing his now classic volume on the Jurassic, Arkell outlined two objectives:

to present a unified description as a reference work and . . . to enquire what can be deduced as to faunal realms, climate, palaeogeography, volcanic and plutonic activity and earth movements ... during one reasonably circumscribed period of geological activity.

Accepting these as the true objectives of any comparable work, one must say immediately that the principal authors here (R. Wolfart, E. Klitzsch, I.C. Rust and M.G. Laird) have dealt nobly with the reference aspect. They have brought together details of successions in some of the least-visited and least hospitable terrains on Earth and have provided valuable correlation tables and palaeogeographic maps. Their chapters will remain the standard references for the Middle East, Libya and adjacent territories, southern Africa and the Ross geosyncline for years to come. As a bonus, there are interesting chapters on Lower Palaeozoic trace-fossils in Africa (T.P. Crimes) and palaeoclimatology (N. Spjeldnaes).

But what about Arkell's second objective? The unity of outlook and stylistic grace which he brought to the Jurassic are perhaps unlikely to be achieved in a volume with many authors: one could, however, justly look for a broad treatment of geological events in Lower Palaeozoic times. A four-page introduction by R.M.
Shackleton reminds us that the areas dealt with are linked by and partially coincide with one of the world's major systems of mobile belts - the Pan-African - which was active immediately before and sometimes during the Cambrian period. Scarcely a mention of this relationship is to be found in the rest of the book, with the honourable exception of the Antarctic chapter. An opportunity seems to have been lost here, though the long-suffering editor (C.H. Holland) whose frustrations are outlined in the preface, may well protest that to have asked for a broader treatment would have made his labours impossible.

Nonetheless, a fuller introduction or a final review chapter might have made all the difference. Stratigraphy is the senior branch of historical geology, but can it any longer afford to close the door on tectonics, metamorphism and magmatism?

Janet $V$. Watson is a Professor in the Department of Geology at Imperial College, University of London.

\section{Landmark of early man in Britain}

\section{Paul Mellars}

The Lower and Middle Palaeolithic Periods in Britain. By Derek A. Roe. Pp.340. ISBN 0-7100-0600-4. (Routledge \& Kegan Paul: 1981.) £35, \$95.

NO ONE is better qualified to write a book on the earliest stages of human occupation in Britain than Derek Roe. For the past 20 years he has been involved in detailed firsthand work on the sites of this period, and has produced not only the authoritative gazetteer of the major Palaeolithic localities in Britain, but also the most exhaustive typological analysis of the archaeological assemblages themselves. The appearance of this general survey of the earlier Palaeolithic material must therefore be regarded as a major landmark in studies of the period in Britain.

Two features of the book are particularly impressive: its evident authority in dealing with the difficult interpretative issues involved and its readability. Dr Roe writes with a degree of clarity, style and fluency which is all too rare in archaeological literature. Some might say that the book is over-written in places, but this kind of judgement must depend to a large extent on the kind of readership which is anticipated. Dr Roe has clearly aimed at an audience which includes not only the specialist prehistorian but also the "interested layman", and for this mixed readership his style of presentation is probably ideal.

To pick out particular features of interest in a book of this scope is an almost impossible task. Perhaps the most significant single feature which emerges from the discussion is the rapidly increasing evidence for the occupation of southern Britain by hand-axe-using communities at some point substantially prior to the Hoxnian interglacial. Roe's arguments for believing that sites such as Fordwich (Kent) and Kent's Cavern (Devon) belong to this early phase are to my mind almost conclusive, and for these sites an age of at least 350-400,000 years would, from several lines of evidence, seem reasonable. Equally interesting from a somewhat different standpoint is the rather curious dichotomy between hand-axe and non-hand-axe ("Clactonian") industries which has been documented for the Hoxnian interglacial itself. This dichotomy - probably clearer in Britain than anywhere else in Europe remains one of the most intriguing problems in Palaeolithic archaeology, for which a really convincing explanation still remains to be found.

Evidence for the later stages of Lower and Middle Palaeolithic occupation is still infuriatingly vague. Uncertainties of stratigraphic correlation, coupled with the lack of any reliable technique of absolute dating, renders any analysis of occupation during the Wolstonian and Ipswichian periods exceptionally difficult. As Roe points out, there is a wide variety of industrial variants which must belong at some point within this time range, but in the absence of reliable dating any discussion of the meaning of this variation (chronological? cultural? functional?) must remain largely hypothetical and the question of interpretation open.

One criticism that might perhaps be levelled at the book is that at some points it verges on the parochial, paying only limited attention to contemporaneous developments in other parts of Europe. In the assessment of the earliest Palaeolithic industries this kind of comparison would certainly have been useful, and perhaps even more so in the discussion of the Middle Palaeolithic sites. But this is at most a minor criticism and can hardly detract from the overall value of the book. Dr Roe's major achievement is to have brought together a remarkably wideranging and diverse body of data, and to have presented it in a clear, well-integrated and easily accessible form. By performing this task, he has produced what is clearly a classic of British prehistory that will serve as the definitive account of this period for many years to come.

Paul Mellars is a Lecturer in Archaeology at the University of Cambridge. 